SMALL-SCALE PRIVATISATION IN EASTERN EUROPE AND RUSSIA: A HISTORICAL AND COMPARATIVE PERSPECTIVE

János Gács, Il'dar A. Karimov, and Christoph M. Schneider International Institute for Applied Systems Analysis, Laxenburg, Austria

RR-93-14

September 1993

Reprinted from Communist Economies and Economic Transformation (1993) 5(1):61-86.

INTERNATIONAL INSTITUTE FOR APPLIED SYSTEMS ANALYSIS Laxenburg, Austria 
Research Reports, which record research conducted at IIASA, are independently reviewed before publication. Views or opinions expressed herein do not necessarily represent those of the Institute, its National Member Organizations, or other organizations supporting the work.

Reprinted with permission from Communist Economies and Economic Transformation (1993) 5(1):61-86.

Copyright (C) 1993 Centre for Research into Communist Economies.

All rights reserved. No part of this publication may be reproduced or transmitted in any form or by any means, electronic or mechanical, including photocopy, recording, or any information storage or retrieval system, without permission in writing from the copyright holder.

Printed by Novographic, Vienna, Austria. 


\section{Foreword}

Small-scale privatisation (SSP) of shops, restaurants, and other consumer services was the first stage of the complex process of privatisation in Eastern Europe and the Russian Federation. It was a giant social and economic experiment to assess the demand for previously state-owned property and people's attitudes towards private ownership. It was also an in-depth examination verifying different techniques of privatisation. Recent experiences of SSP in Eastern European countries and the Russian Federation, although broadly publicised by the mass media, were barely analysed in a comparative perspective. Since the majority of the former communist economies are already undertaking full-scale privatisation, or at least elaborating the programs for it, the time has come for the analysis of experiences already accumulated during the first stage.

This paper, prepared under the auspices of the Economic Transition and Integration (ETI) Project, is one of the first serious attempts to focus on small-scale privatisation from a comparative point of view. The authors, members of IIASA's ETI Project, have meticulously documented recent developments in SSP in the former Czech and Slovak Federal Republic, former Eastern Germany, Hungary, Poland, and the Russian Federation. The paper examines the characteristics of each stage of the privatisation processes and compares them across the nations, beginning with the emergence of the idea of SSP, through legislation, and the rise of unexpected tensions during the implementation phase. The characteristic features of the newly privatised retail and service businesses are also reviewed.

Peter E. de Jánosi

Director 


\title{
Small-scale Privatisation in Eastern Europe and Russia: A Historical and Comparative Perspective
}

\author{
JÁNOS GÁCS, IL’DAR A. KARIMOV \& CHRISTOPH M. SCHNEIDER
}

Small-scale privatisation (SSP) is an integral part of the transition to a market economy in the economies of Central and Eastern Europe (CEE) and the Russian Federal Republic (RFR or Russia). Throughout these nations a predominant hope has prevailed that SSP would constitute the fastest, easiest and most welcomed part of the complex privatisation process and additionally serve as a catalyst for the development of a wide cohort of entrepreneurs. These virtues of SSP were expected to be a major contribution to the evolution of competition, the unfolding of a market economy and the balancing of the hardships the population must endure as a consequence of the crisis accompanying the process of transition.

While small-scale privatisation is still in its infancy in Russia, it is well under way or close to completion in the neighbouring former socialist countries to the west. The smaller CEE economies differ in terms of their initial conditions, privatisation legislation, techniques employed in SSP, the level of public satisfaction with the results of SSP, and other factors. Consequently the study of these issues could be beneficial for the advancement of SSP in those nations with substantial privatisation still to be undertaken.

The potential to benefit from and assess the applicability of the experiences of CEE countries motivated the Committee for the Management of State Property of the RFR to ask IIASA to organise a workshop that leading officials from the responsible agencies for SSP from these smaller countries would attend. As a result, top officials and experts from the Ministry of Privatisation of Poland, the Ministry of Industry and Trade and the State Property Agency of Hungary, the Ministry of Administration and Privatisation of the Slovak Republic, German, Polish and Hungarian economic research institutes, and IIASA gathered in Laxenburg in late June 1992. They met with the department chiefs from the Committee for the Management of State Property of the RFR designated by Anatolii Chubais, Deputy Prime Minister of the RFR and Chairman of the Committee. At the meeting the exchange of individual nations' experiences in small-scale privatisation, and especially the combination of leading policy makers with hands-on experience and research scholars specialising in background material and analysis of results, helped to achieve a balanced perspective on the topics under discussion.

Dr János Gács, Dr Il'dar A. Karimov \& Dr Christoph M. Schneider, International Institute for Applied Systems Analysis (IIASA), A-2361 Laxenburg, Austria. 


\section{J. Gács, I. A. Karimov \& C. M. Schneider}

The original version of this paper was prepared as background material for the meeting. That paper and the accounts of the various national experts and ensuing discussions together form the intellectual basis for this up-to-date description of SSP in the CEE countries and Russia.* The information we collected during this workshop has been complemented with background material (see the list of references) and with the information the authors acquired on their study trips to Budapest, Moscow, Prague and Warsaw during 1991-92. The characteristics at each stage of the privatisation processes were thoroughly analysed and compared across the nations, beginning with the emergence of the idea of SSP, through legislation and the rise of unexpected tensions during the implementation phase, to the particular features of newly privatised retail and service businesses.

Emergence of the Idea of SSP-Principles, Legislation and Techniques of Smallscale Privatisation

\section{The Czech and Slovak Federal Republic}

SSP legislation was approved on 1 October 1990 (The Law on the Transfer of State Property and Some Goods to Other Juridicial or Natural Persons). The legislation defined small-scale privatisation by two features: the business to be privatised would not carry on any obligation of the previous owner (debt, other obligations like training apprentices, etc.), and the only method to be used was to be the auction. The legislation did not define the maximum value or activity of a particular unit to be privatised under SSP. Thus, any type of retail, wholesale and even manufacturing enterprise could have been privatised under the guidelines of the SSP programme. The largest items sold in the course of Czechoslovakian SSP exceeded a value of CSK 100 million (US\$ 3-4 million).

The auction was seen as the most transparent method for unbiased distribution. It allowed some adjustment if the original assessment of the value of the unit to be privatised turned out to be unrealistic. The auction was also regarded as the method that was least open to corruption.

The ultimate decision power in SSP was in the hands of the Ministry of Privatisation. Privatisation commissions were formed in every district; in Slovakia, for instance, there were 38 such districts. Each commission made a list of businesses to be auctioned. The municipalities and local governments were advising on the inclusion or exclusion of particular businesses. The managers of the business were obligated by law to make all the necessary data regarding the enterprise available within 30 days. After the lists were discussed with the local authorities and branch ministries, the Ministry of Privatisation had to give final approval. The commission was responsible for publishing the list in the press at least 30 days before the auction. In order to participate in an auction, persons were required to pay a refundable fee equivalent to a deposit of $10 \%$ of the starting price ${ }^{1}$ or CSK 10000 (US\$ 300-350). The price determined in the auction had to be paid 30 days thereafter.

During the preparations for the SSP some general principles were followed to preclude the emergence of monopolised private retail trade. Giant retail trade companies responsible for the supply of whole counties were split up into several smaller units, while the wholesale activity of these companies was concentrated in one of the new units created from the old company.

The goal of SSP in the CSFR was not to achieve the highest possible price. 
The true objective was simply to reduce state ownership and to create an indigenous business class. This is why legal persons founded in the previous socialist system (like state-owned enterprises) were precluded from participating in the auctions and also foreign (physical or legal) persons were allowed to enter only in the second round of auctions, that is, if the first auction for a given unit turned out to be unsuccessful.

Auctions were carried out by independent committees. The auctions were divided into two groups depending on the character of the items:

(1) the whole entity, including land and buildings; and

(2) enterprises located within the building, that were not the property of the building owner. In this case, the inventory and equipment were auctioned, not the opportunity to rent. The successful bidder then obtained the right to make an agreement with the owner of the building for a two-year (extended in October 1991 to an obligatory five-year) rental agreement.

If the auctions were faced by a lack of demand, then the law allowed the modification of the auction to the 'Dutch' form, in which the initial (starting) price could be successively reduced. In the first round, prices could be reduced to $50 \%$ of the original price by increments of $10 \%$. In case the first round did not result in a sale, a second round followed in which prices could be allowed to decline to $20 \%$ of the original price. The only limiting condition for a 'Dutch' auction was that at least five persons had to take part in this event. Out of the 15000 to 19000 auctions in the process of SSP, about 1500 had to be concluded in the 'Dutch' manner.

Tradition made it difficult to determine the appropriate method to identify the most reasonable starting price. Originally, the depreciated value of buildings and equipment was simply used. The distorted pricing system under communism rendered this system inadequate. In May 1991 a special decree was passed on how to compute the prices of businesses. Two multiplier coefficients, based on the original price of buildings and machinery and on the year of privatisation (the age), were used. After some months, the coefficients were thought to be too low, and they were increased in late 1991. This intervention later turned out to be excessive because the computed prices of land and buildings were then above the market value, making them difficult to sell.

The revenue from SSP is kept separate from the state budget for antiinflationary reasons. In the one and a half years before June 1992, CSK 14 billion were earned as a result of privatisation. Some of this revenue has been used for the privatisation process.

During the preparation of the privatisation law many employees of enterprises to be privatised requested exceptions and special preferences. The request for closed rounds of auctions, restricted solely to employee participation, was one of the most popular among them. As for additional pressure, trade unions threatened industrial action and strikes. While the governments were divided on the issues, eventually both the majority of the three governments (the ministers of economic affairs in the Czech, Slovak and Federal governments) and the Parliament rejected the granting of any preferences for the employees of the units to be privatised as part of the SSP process. 


\section{Former East Germany}

After World War II, East Germany was still a centre of flourishing private enterprise, particularly in retail trade, services and light industry. In 1950 this sector employed $42 \%$ of the work force and accounted for $31 \%$ of GNP. However, by the early 1970s it had, for all intents and purposes, been eliminated. Most of the small and medium sized businesses had been absorbed into the oversized administrative, integrated enterprise organisations called Kombinate. In 1989 the private sector produced only 3\% of GNP, but was still most active in retail trade and services.

We need not emphasise that the German process of privatisation is a very special one. The legislation that was required to facilitate SSP was essentially a function of the unification process of the two Germanies in 1990. Firstly, this encompassed the monetary union with West Germany and the acceptance of the general laws and business practices from West Germany, and secondly, the establishment of the trust agency, the Treuhandanstalt. The Treuhand, as it is commonly referred to, was actually established by the last communist government on 1 March 1990 as a trust company and was transformed into a state holding company to manage and ultimately privatise state property by a modification of the earlier law on 17 June 1990. Initially all state property was transferred to the Treuhand, which in turn changed the existing enterprises to either joint stock companies or limited liability companies. After dealing with some complications involving restitution problems, a speedy SSP programme was introduced.

Restitution was a major obstacle for East German privatisation. The process was seriously hindered by unresolved problems of restitution until late March 1991, when the so-called 'Speed-up Law', which modified 11 existing laws, 130 regulations, and a new law and 62 new regulations were introduced. These new regulations made it possible to compensate previous owners with cash rather than their original property.

In the area of the former German Democratic Republic the decisions to put property up for auction were made by commissions. These commissions were made up of local government personnel, other state officials, and members of the Treuhand. The Treuhand dealt with all the property of the 126 giant Kombinate (integrated enterprises containing small and medium-sized firms) and over 2000 retail enterprises belonging to local authorities. Generally, the SSP was undertaken by regional offices of the Treuhand, while only the largest units were handled by the head office.

East German privatisation could actually proceed both from the top down and from the bottom up. The latter method was facilitated by the introduction of the so-called 'Split-up Law' (division of vertically integrated enterprises into profit centres), while the former was operationalised by the establishment of as many as 5000 boards of directors consisting mostly of West German managers. This process created the units for small-scale as well as large-scale privatisation. After privatisation, the Treuhand guarantees loans to new enterprises and assists financing through banks.

Competitive (sealed) bidding campaigns (also referred to as investment contests) were organised for shops up to $100 \mathrm{~m}^{2}$ and restaurants/pubs up to 160 $\mathrm{m}^{2}$. These competitions were published in regional and inter-regional newspapers only one week before the auction. The purpose was indirectly to restrict 
access to outsiders. (There were no direct restrictions on foreign or West German capital in place.) As a consequence, $80 \%$ of the businesses were sold to native East Germans. In the service sector, though, many services were simply taken over by the communities (i.e. transport, health care, etc.). In the process of SSP, the task and obligation to take over the type of activity and maintain the existing employees were transferred to the new owner.

\section{Hungary}

Until the end of the 1980s, retail trade in Hungary was characterised by a dominance of large trade networks owned by the state or cooperatives. They were in a quasi-monopoly position on the markets for certain product groups or in certain regions. In spite of these networks, however, the importance of private shops also grew most significantly during the last decade. By 1990 the share of private shops had reached $56 \%$ in terms of the total number of shops and $20 \%$ in terms of total retail trade turnover. The number of private trade companies also radically increased: by 1988 their number was almost 3000 and their share in the total trade turnover was $1.5 \%$.

On the initiative of the government, a great number of outlets of the large trade networks were contracted out or leased to private entrepreneurs from the early 1980 s onward. This system has several advantages; namely, as a consequence of these entrepreneurs' profit motivation the supply of products in the shops and the level of service improved. However, the strange situation developed where a growing part of the revenue of the state-owned trade networks originated from the rents paid by the entrepreneurs. The centres of many of these networks seemed to become sheer parasites, collecting an additional rent over that paid to the owners of the premises, the local authorities. The system reached its peak in 1989, when the trade turnover of the leased shops (contractual or rented) exceeded the turnover of the shops functioning in the traditional manner.

The inefficiency of this system eventually gave rise to the idea that the original companies should be abolished and their assets divided into a number of smaller shops, thus enabling potential entrepreneurs to rent the shops directly from local authorities. In officially discussing this idea, Hungary in fact became the first of the small CEE countries to put SSP on the agenda of economic reform. However, for different reasons, Hungary's programme turned out to be the least ambitious and the tardiest in the region, both in its objectives and its implementation. The reason for this lay partly in the substantial and growing private sector in Hungarian retail trade and services by 1989. The original idea of the SSP led to much controversy in 1989. The major argument against it, expressed mostly by managers having a vested interest in the old form of state retail networks, was that breaking up the networks would put the shops into a defenceless position vis-à-vis their suppliers, the huge state industrial enterprises.

The SSP law was finally adopted in August 1990 and came into force at the end of September, and the programme actually started at the end of that year. One of the reasons why this SSP law was eventually adopted and called the PrePrivatisation Law (indicating the type of privatisation that must precede other privatisation programmes) was the recognition by both the government and the deputies in parliament that without an urgently needed immediate step for- 
ward, 'wild' or spontaneous privatisation would soon make SSP meaningless. As a matter of fact, between summer 1989 and August 1990, in the phase of the so-called spontaneous privatisation, several huge trade companies were transformed into limited liability companies and formed joint ventures with foreign companies. Many of the managers of these state companies made major efforts to arrange a very rapid (complete or partial) transformation of their company because they feared that the introduction of SSP would lead to a break-up of their original firm. This rush for transformation-based on laws like the Company Act, Act on Foreign Investments (both of 1988) and the Transition Act (1989) - meant that by the time the SSP programme started, a great number of shops no longer conformed to the definitions of the SSP Law. In fact, many of the most valuable shops had already been sold, and the ensuing revenue invested in a way in which it was no longer subject to state jurisdiction.

The SSP law put the SSP programme under the control of the State Property Agency (SPA). This law covered businesses, workshops and consumer services already functioning on lease or other contractual basis. 'Small scale' was defined by the number of staff, not exceeding 10 in retail trade outlets and 15 in catering establishments. In the case of the hotel business, consumer services and petrol stations, small scale was defined by a limit regarding the turnover of the unit. All units were to be sold at auctions: the initial price had to be determined by the SPA. The price was the main and only criterion of success in the auction.

The general principle of Hungarian privatisation practice is to sell businesses for their real values rather than give them away free, even at the expense of more rapid privatisation. While this principle has been challenged many times in the last few years, modifications of the procedures helped only a little in speeding up different programmes of privatisation. One such recent modification in SSP, which we will elaborate later, reveals the possibilities for a major group of shops to avoid auctioning. There are no conditions in the privatisation programme that call for granting preferences to previous tenants or employees of the outlet. The only exception occurs in case of equal bidding, when the previous tenant and employees enjoy priority.

In an effort to speed up SSP, Hungarian policy makers decided early that claims for full restitution of previous owners would not be entertained. The principle of compensation that was accepted by the parliament, much later than the SSP law (in the middle of 1991), states that previous owners are compensated for their nationalised property to a certain extent only and in the form of bills of restitution. These bills can be utilised in limited ways, bidding for outlets in auctions included.

In some cases (in the case of food shops, bookshops, etc.), the new owner/ tenant had to guarantee that the profile of the shops would be maintained for a certain period of time. In the majority of cases not ownership but only the right to rent for 10 years was sold. Outlets covered by the SSP could only be sold to Hungarian citizens; foreigners were not permitted to take part in the auctions.

The legislation also permitted retail outlets to be auctioned several times. An auction is deemed unsuccessful if the expected value determined by the State Property Agency is not reached. In other words, if the reserve price is not attained as a result of the bidding process. In such a case, the unit would be re- 
auctioned in a so-called 'simplified auction', to which only the most serious bidders are invited.

\section{Poland}

After 1947 the communist takeover effectively suppressed and destroyed private retail trade and consumer services in Poland. This major event of Polish history had reverberations throughout the next 40 years as reflected in the waves of centralisation and decentralisation of trade; the last minor decentralisation campaign was initiated in 1981.

The private sector's share in Polish retail trade, however, started to increase substantially only in 1989, before the wave of SSP. This growth was parily a response to liberalisation measures making it possible for citizens to start new businesses and partly a reaction to the huge shortages of consumer goods in state shops. The number of retail trade outlets jumped to 72000 from the previous year's 43000 , not to mention the tens of thousands of unregistered vendors conducting business in city streets and squares.

Small-scale privatisation of existing state outlets started in early 1990 and gained a momentum in the middle of that year. SSP in Poland has not been guided by a single, specific act. Accordingly, in order to understand the pattern of events one must refer to several acts, as well as to the major turn in macroeconomic control and economic policy initiated in Poland in early January 1990.

Polish SSP refers to those 100000 businesses, mostly shops and consumer services, wholesale and retail trade enterprises, where the founding organ was typically the mayor or the municipal council of the locality. The legal status of these municipalities was formed by three major events in 1990. First, free local elections were conducted on 27 May. Second, on the same day municipalities obtained a legal identity and limited financial independence. They were also granted property rights over business premises (land, building plots, shops, restaurants, flats) as well as those of about 1600 companies. This meant that the long-standing agreements between the owner of the space (most frequently the community) and the user (one of the several hundred large enterprises) had been cancelled. The owner of a building, the local authority, could then independently decide and negotiate with potential tenants. The third important event was the Act on Local Self-Government adopted in May 1990. This completed the formation of an independent local owner capable of initiating and controlling a fully decentralised process of SSP. In fact, this is the most important characteristic feature of Polish SSP: the extremely decentralised and unregulated manner, coupled with a relatively fast pace.

Two additional laws enhanced the unfolding of the SSP process: the Act on Economic Activity (effective early 1989), and the Housing Act (June 1990). The first of these two acts granted each citizen the right to set up a business without the need to obtain special permits or licenses, while the second excluded trade outlets like shops from the special arrangement in which rents had been set centrally by the Council of Ministers.

In addition to this legal framework, the central government only made recommendations on a limited basis to the local authorities in charge of privatisation. This lack of central control resulted in a remarkably large variation in the methods by which local authorities arranged the privatisation 
of the outlets they had possessed. Even if some regular patterns have emerged in the process of privatising the several tens of thousands of outlets under the auspices of the 2700 municipalities (like the overwhelming dominance of lease privatisation over outright sale or the rarity of unrestricted auctions), these were more the result of implicit legal constraints or social relations than of any explicit central regulation or directive.

\section{Russia}

Russia is a unique nation in many ways. In Russia there is practically no living memory of small entrepreneurship as there was in the other CEE economies. Private trade was virtually eliminated in Russia a quarter of a century or more before it was in the other CEE nations. Correspondingly, central distribution has its deepest roots in Russia. One of the greatest obstacles to the implementation and success of SSP in the RFR is a direct result of the aforementioned factors, namely, the psychology of the population.

The actual process of SSP began in early 1992, although several occasional auctions were registered in various parts of Russia during 1990-91. Since then, the process was chiefly motivated, initiated and directed by the central government of the Russian Federal Republic (RFR). A number of decrees signed by President E'ltsin since November 1991 had facilitated the key breakthrough to implementing privatisation procedures. These included:

- Foundations of the State Programme of Privatisation for the Year 1992;

- On Commercialisation of Trade;

- On Commercialisation of Consumer Services; and,

- On Freedom of Trade.

In addition, the Supreme Soviet of the RFR had passed the act On Separation of State and Municipal Property on 27 December 1991. This decree was essential for the reorganisation of trade controlled by large industrial ministries and opened the door for regional privatisation committees to begin active privatisation. Since then, SSP became fully legitimate and received true legal status in Russia and, more importantly, the strong support of central authorities.

In late 1991 and early 1992 the start of commercialisation ${ }^{2}$ and the ensuing liberalisation of retail trade created an appropriate environment for the beginning of mass SSP. In fact, until as recently as the middle of April 1992, half of the retail trade and consumer services outlets in Russia were still not commercialised. In addition to possessing no separate assets, balance sheets or bank accounts, these outlets were also not legal entities. ${ }^{3}$ At that time, between $40 \%$ and $60 \%$ of all retail trade and services outlets in Russia were still exclusively the property of one or other of the large regional trade monopolies. There had been 1800 of these vast organisations in Russia, entirely controlling the supplies, stocks, distribution, sales, finance and accounting of their retail branches.

Among those outlets already commercialised, most are small and still largely depend on their former 'parents' owing to the generally high level of monopolisation of supply, storage and transport networks, not to speak of the inexperience of personnel and the infancy of banking infrastructures. Nevertheless, "the 
ice was broken' and, since then, millions of people have tasted the spirit of small entrepreneurship as either consumer or sales staff.

Mass SSP in Russia officially began on 5 April 1992, when local authorities successfully auctioned over 20 cafes, shops and other commercial retail outlets at the first regular auction in Nizhny Novgorod. ${ }^{4}$ The International Finance Corporation, the private sector arm of the World Bank Group, has drawn on the lessons of CEE countries in order to design a unique privatisation project in Russia's third largest city. Experts from Poland and the CSFR joined the international team. The plans were to sell 2500 of the city's retail trade and services operations by the end of 1992 .

In an effort to equalise the vast geographical variation in rates and breadth of SSP, Russia was divided into 88 regions and a regional privatisation committee established in each one. In the initial phase of SSP there had been no true links between the central and the 88 regional committees. Following unsatisfactory results in the distribution, extent and speed of privatisation, which were in part attributed to the lack of active ties between the regional and central committees, the former were subsequently directly subordinated to the Committee for the Management of State Property of the RFR in Moscow. Further reasoning behind this move was that, in Russia today, the central government is recognised as more progressive and reform-oriented than the local authorities and committees. It is not too surprising that this has resulted in a very hierarchical structure, but the Committee has argued that this is a necessity to speed up the process and reduce the influence of local apparatchiki.

According to the legislation, starting prices of outlets are set at their book value in 1979 prices. As a consequence, and also thanks to the extensive investors' interest, selling prices of outlets were many times higher than the starting prices. There has so far been no case in which a foreign investor has bought outright a retail trade or service enterprise, despite the large number of foreign firms leasing hundreds of premises for retail trade, mostly in Moscow and St Petersburg. Yet the present leasing agreements of these foreign firms do not automatically give them the right to buy the outlets once the leases expire. The participation of legal and physical entities from other republics of the former Soviet Union has also been very weak, although these people are not yet generally considered to be foreigners.

In Russia SSP is not hindered by claims for restitution, as has been the case in most of the smaller CEE nations. In Russia there are no grounds for restitution. Previous owners and their descendants died long ago, documentation was discarded and buildings were ruined. All over the country, only a few claims of former owners were registered, but none were even considered in a court of law. The legislation does not preserve the rights of former owners.

On 5 June 1992 the Supreme Soviet of the RFR modified the one year-old law On Privatisation of State and Municipal Enterprises in the RFR. As far as small-scale privatisation is concerned, auctions have become the predominantly accepted procedure for the sale of both insolvent and well-functioning enterprises. This should effectively put a halt to giving away enterprises to employees, which has become an all too popular strategy in several regions. The new version of the law also includes a package of anti-monopoly measures: for instance, it forbids mergers and acquisitions in the process of privatisation, as well as termination of earlier existing legal entities. The changes have signifi- 
cantly strengthened the legislative power of the Committee for the Management of State Property.

On 11 June 1992 the Supreme Soviet of the RFR accepted the State Programme of Privatisation for the Year 1992. This document was issued within the framework set out by El'tsin's half-year old decree on the Foundations of the State Programme of Privatisation for the Year 1992. The programme not only confirmed mandatory privatisation of the entire wholesale and retail trade and consumer services sector in as short a period as feasible, but also included in this list units that currently belong to industrial ministries and large state enterprises. ${ }^{5}$

The other important novelty in the programme is that small enterprises with less than 200 employees and a book value on 1 January 1992 (in 1979 prices) of less than 1 million rubles can only be privatised via the auction method at this time. This attaches quantitative criteria to the corresponding article of the legislation. While it may seem obscure, the absolute majority of not only retail but also wholesale trade outlets satisfy these criteria.

According to the estimates provided in the programme, the gross revenue from privatisation in 1992 (including large-scale privatisation, yet to be started) will reach approximately 74 billion rubles, including 15 billion rubles from physical entities and 10 billion rubles from foreign investors. The Committee for the Management of State Property expects essentially to complete SSP in Russia by the middle of 1993 .

According to the State Programme of Privatisation for the Year 1992, the following techniques of privatisation are recognised:

- auctioning of enterprises;

- investment contest with binding conditions (with mandatory competitive bidding at an auction); ${ }^{6}$

- non-commercial investment contest with regulated access; ${ }^{7}$

- auctioning of liquidated or insolvent enterprises;

- buy-out of previously leased property (without competitive bidding); and,

- sale of shares of open joint stock companies.

In addition to the first technique on the list, which has been the most frequently utilised instrument, the other privatisation techniques have also begun functioning to a varied extent throughout parts of Russia. Since the bankruptcy legislation has not began to work on a full scale, there is not a large number of insolvent enterprises on sale yet. An investment contest is technically very difficult and time-consuming: this explains its relative lack of popularity. In contrast, the buy-out of previously leased property is very popular since, back in 1990, a large number of retail and even wholesale trade enterprises became leased companies. The parties permitted to enter auctions and contests are:

- resident physical entities; ${ }^{8}$

- resident legal entities, ${ }^{9}$ if the government share in their property does not exceed $25 \%$;

- any foreign investors with consent from the local soviet.

In general, new owners are not:burdened with legal handicaps, but at the same time they receive few guaranteed benefits. Only in some special cases, like 
employee buy-outs, are there some legal privileges for buyers. According to the law, the employees are required to pay only $20 \%$ of the clearing price immediately and the rest on a three-year installment basis negotiated by the parties upon sale. They also get a $30 \%$ reduction in the price of the lease, which is deducted from the eventual selling price.

If auctioned property belonged to local authorities (the most prevalent case), almost all proceeds go to the local budget with two exceptions: $4.5 \%$ of gross receipts are collected by the Committee for the Management of State Property and another $10 \%$ go to the federal budget. Russian and foreign banks are free to finance would-be investors, but they cannot use Central Bank of Russia credits for such purposes.

Progress Report: Major Problems Emerging in the Process of SSP and Thereafter

\section{The Czech and Slovak Federal Republic}

Privatisation of the retail network began on 1 January $1991 .{ }^{10}$ SSP coincided with the start of economic deregulation. From the beginning of 1991 retail stores had no central orders to fulfil regarding sales or supplies as directed from the state or local governments. Very few of the large state retail enterprises were under ministerial jurisdiction by this time, most were under local or regional authority. From this point onward, prices, inventories, and sales policies were solely the responsibility of the individual retail outlets.

Originally, the SSP in the CSFR was to be on a grand scale with a fast programme of privatisation. Approximately 100000 to 120000 units were to be privatised in a short period of time, but in the middle of the period assigned for the SSP (in October 1991) the Czech Minister of Privatisation declared that no more than 23000 units would be privatised in the programme. The causes of this change were many. A large number of the shops and services establishments could not be offered for SSP owing to the condition requiring them to be free of any previous obligations. Many of the shops offered at auctions did not turn out to be as attractive for would-be buyers as originally thought.

Special rules for restitution (full in-kind compensation of previous owners) also hampered the sale of many shops: the deadline for claims regarding previous property is the end of 1992 and the highest estimate for the percentage of the total number of retail shops to be claimed is $40 \%$. According to the principles applied here, restitution had priority over SSP. No entity could be singled out for privatisation if there were any hints of restitution claims on hand or to be expected. The retail and service outlets that did not find new owners as a consequence of SSP (or original owners through restitution) were not to remain untouched: these will either be privatised in the framework of the large-scale privatisation or will be liquidated.

Even if the original number of units had to be scaled down, the SSP in Czechoslovakia was a relatively fast process. In Slovakia, for instance, over $85 \%$ of the (scaled down) number of units had been privatised by 21 June 1992, either via auction $(67 \%)$ or as part of the restitution programme (18\%). If numerous retail stores under the authority of communities or cities are included, the percentage is even higher. At any rate, the SSP process by auction was to be completed by 30 June 1992 .

Small-scale privatisation has contributed to and stimulated the emergence 


\section{J. Gács, I. A. Karimov \& C. M. Schneider}

of the private sector. The importance of this sector in the whole economy has expanded dramatically. In Slovakia the share of private sector sales revenue quadrupled during 1991 and reached $46 \%$ of total volume in the first quarter of 1992. Slovakia has gone from having virtually no private sector in 1990 to having a full-fledged private sector in retail, services and some manufacturing by June 1992 .

The structure of ownership after privatisation appears to be quite widely distributed. Many of the new owners consist of former employees who were successful in the bidding competitions. This, however, is not the majority. Numerous persons previously outside the retail trade and services sectors have become new owners. This has been very favourable for the development of the private sector and competition because these new people are thought not to suffer from the decades of the existing practices in the sector.

Early in the SSP programme many members of the old nomenklatura and enterprise managers attempted purposely to slow the process by not providing local privatisation commissions with the required statistical basis needed to determine an enterprise's fitness for privatisation. Therefore, guidelines on the compulsory provision of enterprise data had to be entrenched in the privatisation legislation.

While few have questioned the method of auctions as the most appropriate way of privatising small business, the fairness and efficiency of the implementation have often been the source of controversy. One sensitive question was the hidden participation of foreign capital. Many foreign investors did not want to wait until the second round of auctions, leaving the best units for those eligible for the first round. Instead, they participated in the first round as silent partners and thus acquired many units, the number and value of which is still unspecified. These illegal actions were facilitated by some loose regulations: the buyer did not have to explain the origin of the money (many millions or tens of millions of CSK) paid for the outlet, nor whether the source was taxed revenue. Another point of concern was the practice of 'Dutch' auctions, where the law could not prevent collusion between the participants and accordingly many such auctions were viewed with suspicion by the public.

Peaks and troughs quite clearly characterised the prices achieved for outlets at auctions in the CSFR over the last 18 months. In the early months, growth in prices was low owing to caution on the part of buyers and their unfamiliarity with entrepreneurship. Just as prices were rising, a new decree to set higher starting prices caused demand to drop. Prices regained momentum, only to be suppressed again by quasi-legal actions of corrupt forces and racketeers. Government measures to combat corruption led once again to higher prices, but new measures regulating the starting prices caused SSP to slow down and gains to decline considerably towards the end of the 12-month period. Selling prices were initially $50 \%$ to $60 \%$ above the starting prices; the average realised selling price per outlet being around CSK 1 million. In $75 \%$ of the cases only the right to rent the outlet was sold, and it was mostly in these cases that selling prices were much higher than the starting prices.

As for the post-privatisation activity of the shops, the first experience showed that the supply provided by the privatised units often diverged from the standard selection and supply of goods known in the past. This has created particular problems in meeting the demand for industrial products where the former supply standards are still the norm. The very rapid dismantling of the 
retail network among many different entrepreneurs has not guaranteed the preservation of the distribution system as it was, resulting in a shortage of certain goods. On the other hand, the new additions to the selection are usually very similar in most non-food retail shops, namely, imported toys, electronics, perfumes and other household chemicals, consumers goods, and so forth.

Another interesting feature of the renewed activity of retail trade has been provoked by restrictive macroeconomic policies leading to $40 \%$ decline in consumer demand. Faced by this critical problem, new dealers eagerly searched for products that would secure their level of turnover and found that Western imports, no longer limited by quotas, were more appropriate than products produced domestically. As a consequence, the decline in domestic industrial activity is partially blamed on the purchasing policy of newly privatised retail trade units.

\section{Former East Germany}

Privatisation of retail trade and consumer services in the former German Democratic Republic was among the most rapid in CEE countries. The process of SSP started shortly after the establishment of the monetary union with West Germany, midway through 1990. Like in other East European nations, privatisation coincided with general economic reform.

In the year and a half between 1 January 1990 and 30 June 1991 the Treuhand had privatised almost $85 \%$ of the retail trade and service outlets in its SSP programme. By the end of 1991 most of the previously state-owned operations in trade and consumer services had been privatised. Statistical data on the privatisation of former HO (state) retail shops, restaurants and hotels provide evidence of the dynamics of the privatisation process. Out of the 30000 units to be privatised, 9300 were privatised by October 1990 and another 14000 by the end of June 1991. In this second period, two rounds of competitive bidding were organised: the first resulting in the sale of some 11400 , and the second about 2600 outlets. The privatisation of $60 \%$ of the outlets was organised by branch offices of the Treuhand, while the rest was arranged by the head office in Berlin.

The East German case showed that the centrally planned wholesale sector of the old communist days had no future in a privatised retail trade and service economy. In fact, in its previous form, this sector became totally useless and was completely unprepared to function as a modern distribution system. The Germans had two answers; firstly, privatise retail and wholesale essentially simultaneously; and secondly, allow Western wholesalers (primarily West German in this case) to enter the market.

Complete opening of the economy to the West, the breakdown of traditional markets, the inadequate establishment of a mature entrepreneurial environment, and the deficiency of managerial experience to exploit the potential of the re-privatised sector lead to changes in economic structure that were not always beneficial. These factors, combined with a lack of skills in marketing, purchasing, controlling, finance and technology and capital transfers have led to a sort of colonisation of the most interesting and economically profitable activity in the East by the West.

Retail trade was considered an important sector by Western investors. Therefore, the West German retail trade chains were eager to secure shops in 
East Germany. The Spar chain bought 2000 outlets, Edeka 100, Rewe 200 and Engle 413, while other Western retailers preferred green field investments (i.e. those required to build a completely new establishment from scratch). ${ }^{11}$ As a result of this avalanche of Western investment, the concentration of retail trade in East Germany still remained very high, certainly higher than in the western part of the country.

The Treuhand followed a policy of encouraging managers of shops under $100 \mathrm{~m}^{2}$ to buy out their businesses. As a result, $36 \%$ of all management buyouts took place in the trade and service sector. Experts predict, however, that a lack of proficiency and financial power on the part of the new owners may force these shops to close soon in the face of competition from the powerful, giant chains. These financially solid and aggressive firms show an active investment policy in the new provinces and use every tool (like the way the infrastructure is reconstructed) to reshape consumer purchasing habits. A characteristic example is the construction of big supermarkets and department stores along the highway surrounding Berlin.

In addition to management buy-outs, another method of takeover of small and medium-size businesses by East German businessmen was the re-privatisation of those 4000 firms that had been nationalised by the East German state in 1972. Unfortunately, the process of re-privatisation did not gain much momentum in the past year and a half; only $25 \%$ to $30 \%$ of these enterprises could be taken back by their original owners owing to the often extensive alterations in the business premises and the profile of activity.

The third manner in which private initiative could gain ground in the smallscale sector of East Germany was with the growth of new small businesses in retail trade and catering. The initiative to establish new businesses was especially pervasive in 1991; however, by the middle of 1992 a certain balance had been achieved between business openings and closures, the former still being twice as high as the latter. Statistics also indicate that, as a rule, half of all openings and closures take place in the retail trade and catering sector with the monthly openings averaging around 8,000 business units.

\section{Hungary}

Owing to the high initial level of private ownership in retail trade and consumer services, the Hungarian SSP was not envisaged as a programme for a very large number of units, but only for some 10000 . SSP was conceived as a catalyst for the progress of ensuing large-scale privatisation. Neither the experts nor the public took long to realise that the dimensions of the programme were much smaller than had been originally declared and the implementation was extremely slow.

It turned out that of the 10000-10300 outlets that were originally selected for pre-privatisation, a great number were in cooperative or private ownership and accordingly not subject to the SSP law. Another 4700 operated on leasing or other contractual arrangements where the contract made it impossible to privatise the outlet before the expiration of the contract. ${ }^{12}$ By April 1992 the property rights of only 680 outlets had been sold, while the right to rent had been sold in the case of another 1980 . There were 560 additional shops where a form of privatisation other than auction was applied (for instance, by converting or merging into a company). As many as $43 \%$ of the auctions were 
unsuccessful and had to be repeated. The average sale price was about $140 \%$ of the starting price. The revenue from SSP, which reached approximately 8 billion forints (10 billion by August 1992), was to be used primarily to finance past and current national budget deficits as well as the costs of privatisation.

The Hungarian SSP process was also contaminated by some circles that attempted to manipulate auctions, particularly if the starting price was perceived to be too high. This caused variations in selling prices. However, the implementation of the simplified auction under the SSP law facilitated an official reduction of the starting price. Consternation that others could subsequently afford the particular outlet forced the potential manipulators to bid more seriously in the first round in response to this disciplining mechanism.

While the eventual number of shops offered for SSP turned out to be low, the number of unsuccessful auctions was relatively high. This lack of interest on the part of Hungarian would-be entrepreneurs could be explained by two factors. The first is that too few outlets were offered for outright sale and in too many cases only the right to rent the premises was auctioned. Hungarian citizens were reluctant to bid for the latter, because there was no regulation guaranteeing them an acceptable rent in the medium term in their negotiations with the owners, mostly the local authorities. These authorities usually forced the new tenants to take new contracts stipulating a higher, often two or three times higher, rent than previously paid by the state-owned shop in the same location. The other factor was the lack of preferential credits to be used in the SSP. In summer 1990 the government promised to provide a so-called Existence Credit for this purpose, but the Ministry of Finance and the banking system took almost a year and a half to elaborate the precise conditions of this credit.

Owing to the obstacles mentioned above, the new Hungarian entrepreneurial class habitually found it more rational and less expensive to start a business from scratch rather than buy an existing one via the SSP programme. By the end of 1991 about 150000 private retail traders were registered (half of them emerged in 1991), as opposed to the 3000 outlets sold in the framework of the SSP. Unfortunately, this turn away from existing premises has begun to reduce the average level of quality, selection and service offered by these frequently single-person enterprises because their location and facilities are often inferior to those of the existing shops.

In any case SSP played a limited role in transforming the Hungarian retail trade sector. In the privatisation of the existing retail trade, the selling of large trade networks in one piece (not under the SSP programme), played a larger role. The 3000 outlets which were privatised in SSP constituted less than 12\% of the existing state outlets in 1988 .

One of the major controversies concerning the privatisation of Hungarian retail trade was whether large retail trade chains should be privatised in one piece-in the framework of invited or advertised bidding, through negotiations with the SPA-or by units within the framework of the pre-privatisation programme. As mentioned above, many networks had already made themselves inaccessible for SSP by steps undertaken in the phase of spontaneous privatisation (for instance by transformation to joint ventures with foreign participation). Additionally, the SPA's insistence on achieving the highest revenue from privatisation meant that many networks of specialised retail trade outlets, department stores and hotels offered for sale in one piece were extremely 


\section{J. Gács, I. A. Karimov \& C. M. Schneider}

costly; consequently, most were sold to foreign investors. On the whole, such networks as a single piece usually proved too expensive for domestic buyers.

Newly privatised retail trade businesses in Hungary had to face a market full of new difficulties on the one hand, and a market showing certain signs of improvement on the other. In the past two years, restrictive government macroeconomic policies caused consumer demand to decline by an annual $15 \%$. Retail trade had to cope with a massive shrinkage of the market.

Simultaneously, however, the access of the trade sector to products in high demand improved dramatically. The cause of this was partly the progress of import liberalisation and partly sales problems of Hungarian producers in Eastern Europe. Upon losing their potential markets in Eastern Europe, these producers were forced to court domestic retail traders in order to persuade them to select their products for sale. This turn of events helped retailers to attain a more balanced position vis-à-vis the wholesale enterprises. ${ }^{13}$

The short-term experience with retail chains taken over by foreign investors is not unambiguously favourable. Some of the new owners did not modify the supply or service of the old shops, but just changed the name of the network and adjusted the prices upwards. Others introduced a selection of up-market products which masses of Hungarian consumers, suffering from the effects of current recession, could not afford to buy. A number of the new owners of these networks showed a surprising insensitivity to the actual demand of Hungarian consumers. They seemed to be less interested in making money in their new business and more satisfied with having gained control over valuable premises on the best sites in the Hungarian capital and other major centres.

As for the quantitative description of the behaviour of new privatised smallscale retail trade businesses, we may summarise here some findings of a recent survey conducted by the KOPINT-DATORG Institute in Budapest. ${ }^{14}$ The owners/tenants of newly privatised units displayed quite dynamic activity. More than $57 \%$ of the respondents made investments in their shop and more than $50 \%$ planned to undertake significant changes (investments) in the near future. Almost one-third of the new owners/tenants changed the profile of the shop: 57\% of them broadened the profile while only a very few narrowed it. About twothirds of the entrepreneurs bought their outlet using credit. The 300 respondents to the survey on the progress of SSP raised loans from 14 different banks.

The majority of the new owners/tenants use standard suppliers, mostly the traditional, state-owned wholesale trade companies. This seems to be a special feature of the pre-privatised small shops since, in the other sectors of retail trade, experience shows that a growing number of the firms try to bypass wholesale traders and purchase directly from producers or from importers.

About half of the respondents revealed that the newly privatised shop was not his/her first venture, and $40 \%$ of them still operate one or more additional businesses. This feature indicates that those who participated in the SSP were not without previous experience; the great majority of them joined the entrepreneurial sector during the 1980s. In fact, to buy a shop in Hungary for some million Hungarian forints (even with credit) is a risky venture and it would have been even more risky for people with absolutely no previous experience.

\section{Poland}

After the election of new municipal authorities, these new administrative 
bodies embarked on a vigorous campaign of privatisation of the outlets under their control. The Polish population has been identified as always having sufficient funds at their disposal to start small businesses. Also, tax holidays were granted for small businesses during this time. As a result, municipalities saw a chance to gain much revenue by a fast privatisation of retail trade outlets in the face of strong demand.

Owing to a deficiency of detailed regulations other than some general guidelines from the central government, the municipal authorities were permitted to devise their own rules of behaviour for this purpose independently. The outcome was a variety of methods for allocating rental contracts for the premises.

The outright sale of retail premises was perceived as less favourable under the existing conditions. The legal status of the outlets was too obscure for a full transfer of property rights. Yet, even if this could have been solved, the municipalities themselves preferred a continuing flow of budgetary revenue rather than a lump-sum payment for a sale, and also preferred the maintenance of their power as owners and administrators preserved under rental agreements. Even a modification in the civil code in October 1990 to facilitate the outright sale of various kinds of premises did not lead to a substantial rise in outright sales: only $3 \%$ of the units privatised were actually sold by the end of 1991, while the remainder were rented.

The methods of allocating the rental contracts varied from the more administrative, but unclear approach to the less discriminatory, most transparent market technique. Some authorities opted for a practice whereby contracts were drawn up with previous employees or agents who had had a relationship with the earlier business operation of the outlet (i.e. with insiders), excluding all other parties, and agreed on a notional, low fee for the lease. Others organised tenders but for a restricted group of possible buyers only. Another group of authorities preferred the open advertisement of auctions for everybody, and either gave preferential treatment to insiders or granted equal treatment to anyone expressing interest. The variety of the methods used by municipalities is well reflected in the fact that the employees of retail outlets were treated differently in different districts of the same city, as was the case in Warsaw.

Despite the great variety of methods, privatisation was biased towards administrative allocation of rental rights versus allocation through the market. While in Czechoslovakia and Hungary the application of open auctions was a rule, in Poland they were exceptions. Out of the 43000 rental agreements concluded within the framework of SSP, only $4 \%$ were completed through unrestricted, open auctions by June 1991.

Municipalities showed a clear preference for insiders in the allocation of rental agreements. This bias has been achieved partly by various forms of pressure from groups of insiders: they demanded favourable treatment and low fees for leases; they were extremely well organised and supported by trade unions. Administrative allocation favouring insiders also resulted in lease fees that were usually much lower than the fees achieved through open auctions (the latter were 10 to 100 times higher than the former). This fact explains why closed allocation of leases was so vulnerable to corruption and other negative aspects.

Municipalities were not regulated by prescriptions from the centre. However, as a consequence of their similar thinking and vested interests, they 


\section{8}

J. Gács, I. A. Karimov \& C. M. Schneider

tended to issue similar resolutions concerning SSP. For instance, many municipalities imposed two conditions on the insiders with whom they intended to make a contract. First, the insiders had to form a partnership or limited liability company comprising all the existing employees or at least $50 \%$ of them and, second, insiders applying for the rental agreement had to be employees in the given outlet for a predetermined period of time (this latter condition served to exclude influential outsiders, like old nomenklatura members, from the preferences granted to insiders).

While the new municipalities were totally unprepared for the tasks required for the organisation of the SSP, and undoubtedly made errors and even transgressions, the pace of SSP in Poland reached a remarkable rate. Different sources show different results: Grosfeld \& Hare (1991) as well as Dabrowski (1991) estimate that $40 \%$ to $50 \%$ of all shops were privatised by the end of 1990, while the Polish Ministry of Privatisation (1991) put this ratio at $80 \%$. According to government estimates made in September 1991, private retail trade turnover amounted to $72 \%$ of the turnover of the whole retail trade sector. ${ }^{15}$

Statistical data, however, indicate another interesting feature of the privatisation process in Poland. In the year 1990 the number of retail trade outlets in Poland increased from 72000 to 346000 . This explosion of private activity clearly cannot be explained only by the privatisation of the 30000 to 50000 outlets previously owned by the state. We should recall a similar characteristic feature in the case of Hungary: the establishment of new businesses from scratch was more frequent than the conversion of previous state-owned outlets and played an equally important, if not dominant, role in the privatisation of economic activity.

Public acceptance of SSP was mixed, but reaction was generally positive. Clearly the ownership changes in tens of thousands of retail outlets contributed substantially to the secular shift in the supply of goods and services in Poland, quickly changing the appearance of towns and the perceived quality of everyday life. However, the implementation of the SSP also raised doubts and caused frustration among the population. The imprecise rules for the implementation of the process, the absence of clear, unified methods of valuation, the inadequate distribution of the information concerning the rules governing privatisation and preferences for insiders all generated tensions and conflicts. Public discontent emerged both when artificially low rents were agreed with selected partners in close negotiations and when exorbitant rents were secured in some open auctions for premises in high demand. Among the ambiguities of the legal framework one must also mention the problem of restitution which, unlike in Germany, Czechoslovakia and Hungary, has not been seriously tackled in Poland.

When the privatisation programme for retail trade began, major questions arose concerning the state of wholesale trade, as it was still highly monopolised in 1990. The retailers had their difficulties with the big state enterprises dominating distribution and wholesaling. The transformation of the ownership pattern in this field remains ambiguous. State wholesale companies lost onefifth of their warehouse space in 1990, most probably through privatisation. Private entrepreneurs also showed vigour in setting up new wholesale businesses: by the end of 1990 about 35000 private businesses were registered as wholesalers or mixed retailers and wholesalers. The government also tried to 
challenge the dominance of state wholesale companies by the liberalisation of imports and establishing freedom to set up importing businesses. The wholesale sector, however, has essentially stayed in the hands of state companies. The main cause was the plan to privatise distribution and wholesale enterprises as part of the large-scale privatisation scheme, which made less progress in the first years of privatisation.

\section{Russia}

The progress of the SSP process has been extremely unevenly distributed in Russia, with some regions far along the path and others not even ready to begin the process. ${ }^{16}$ During the early stages, SSP has been primarily concentrated in large cities. Moscow has taken the lead; however, some experts allege that this can largely be ascribed to the extremely flexible application of SSP guidelines, with independent modifications when so desired. Small outlets are not being auctioned, but rather given away to their workers or employeees (actually, sold at a non-market determined price of 1000 rubles per square metre of total space), preserving monopoly-style operation and leaving the property largely in the hands of the former nomenklatura. Of the 6000 shops privatised in Moscow, $70 \%$ were disposed of in this manner.

The Moscow give-away style of privatisation has been said to encourage the criminal factor. Much capital is supposedly flowing in from the grey economy and is subsequently often behind employee acquisitions. As a result, the SSP has lost some credibility and the receipts from privatisation have not been as high as they could under more virtuous circumstances.

Despite its clear advantage in facilitating a high speed of privatisation, this practice leads to preservation of the previous highly monopolised and corrupt system of retail trade in Moscow. Personnel remaining from the previous system, with their old connections to the upstream monopolies, good level of social security, and historically high incomes (in kind and in cash terms), are confronted with insufficient incentives to develop their businesses. At the same time, the process of creating new small enterprises is much less successful in Moscow owing to the significant level of corruption among local authorities.

The way privatisation has been accomplished in Nizhny reveals a more promising alternative to the Moscow-type privatisation. The weekly auctions in Nizhny have proved to be the most frequented (by sellers and buyers) and the most representative in Russia. By 15 June 199212 auctions had been held at which 120 outlets had been sold. Although these numbers still appear modest, they are increasing rapidly and, more importantly, expanding geographically.

The special feature of the auctions in Nizhny is that what has been sold in $90 \%$ of the cases has not been the outlets themselves but the rights to lease them for five years with additional rights to buy them at an estimated value after the lease is terminated (by 12 June only 10 units had been sold outright). This arrangement was the result of technical reasons: land is not yet the subject of ownership and almost all outlets are located in the ground-floors of bigger buildings, the owners of which are yet to be identified. However, in some other cities, local authorities have managed to solve this problem in some fashion, significantly increasing auction receipts: for instance, in Belgorod two auctions with outright sale were held with an average price of 20 million rubles per grocery store-that is five to seven times as much as in Nizhny. 


\section{J. Gács, I. A. Karimov \& C. M. Schneider}

As mentioned above, early in 1992 a hierarchical structure of privatisation administration had been set up. In May this new structure was put into operation and a combination of administrative and economic measures was implemented via the hierarchical decision-making process. The response over just the next 30 days was a tripling of the rate of privatisation. While earlier the number of privatised shops was a mere 55 , it rose to 800 by mid June. Of course, 800 is still a very small proportion of the 150000 retail shops, 70000 canteens and cafes, and 30000 consumer services outlets owned by the state throughout the country. Most have been well integrated into the large administrative organisations of the city and local administrations. They are a part of the bureaucratic apparatus and are monopolies with respect to activity and/or location. These figures however, do not include the $25 \%$ of retail and service outlets that have traditionally belonged to large vertically integrated industrial enterprises, which were originally to supply workers in the enterprises.

As far as prices of the privatised outlets are concerned, they were on average 50 to 100 times the original book value (also the starting price at the auction) of the premises in Nizhny. The initial surge of interest, reflected by the high prices offered by prospective buyers throughout Russia, was followed by what appeared to be a drop in demand for the privatised units if the trend of selling prices is used as an indicator. In April 1992 the average selling price was 30 times the starting price at the auction, in May it dropped to 25 times, and by June the difference had declined to seven times or less. This phenomenon was not unknown in some CEE economies, and was generally a function of capital availability, expectations, modifications in the regulations, and corruption.

Throughout Russia, receipts from SSP have grown by a factor of 30 over the three months to June 1992. The buyers, primarily from Nizhny's recently emerging commercial sector, have the required 3-5 million rubles readily available to purchase the right to five-year leases of grocery stores, barber's shops or canteens, most of them without binding conditions on the future business profile. (According to guidelines set by the Committee for the Management of State Property, not more than $40 \%$ of the units can be sold on such conditions in urban areas.) Employed personnel of outlets for auction have played an important role in the bidding process. For example, 10 out of the 22 units auctioned on 4 April in Nizhny were bought by their employees. As mentioned above, the interest of 'internal' investors was encouraged by significant advantages.

The first effects of commercialisation and privatisation of small-scale businesses have already become evident: queues have almost disappeared. Nonetheless, people are still running around trying to identify 'the true market price'. Equalisation of prices is said to be just a question of time. However, the problem of supply response has not yet been solved. Most of the upstream industries enjoy a monopoly position and still rely on government subsidies and cheap credits.

More important are the social implications of the privatisation programme. Workers in retail trade and services-once a mighty and spoiled groupbecame as unprotected as everyone else. Local authorities lost their access to cheap subsidised goods: old apparatchiki, like the previously privileged retail trade workers, are also not pleased with the reform. ${ }^{17}$ The regional population, in general, does not oppose the SSP; few protests were reported. In Nizhny, every auction is accompanied by a few pickets of trade workers, retired staff, 
and the so-called 'patriots'. In general, the reform is going well, although, unfortunately, two privatisation-related murders were reported in Moscow. But this is still not comparable with the violence which accompanied the reverse process in 1917 and after.

New owners of retail outlets try to shape their own business policy to fight the consequences of declining consumer demand caused by the current tightening of monetary policy. As a consequence, many of the privatised stores do not sell staples, but rather opt for luxury products that are also out of the average person's price range. Consumers often associate privatisation with price rises that are generally beyond their financial means, particularly if they are pensioners or the poor. So, owing to changes in business profiles and price increases (though they are really a function of the abolition of subsidies), privatisation is often related to the introduction of difficulties into life, and not solely advantages. This influences the psychology towards privatisation, and its acceptance by consumers.

There are a few general problems facing Russian central and local authorities in the process of the SSP. The following is an account of the most important issues at present.

Ownership of premises. In a number industrial cities, retail outlets' premises are not just public but rather belong (up to $90 \%$ in some areas) to large industrial enterprises ${ }^{18}$ which, already in the process of commercialisation, impede the privatisation of outlets. The enterprises are unwilling to give up the outlets, because they would not be able to control the supply of consumer goods for their personnel and, no less important, they would lose effective potential sources of revenue.

Another problem with respect to ownership is characteristic of outlets that have been sold to groups of employees. As the experience of the majority of shops privatised in Moscow shows, the behaviour of these units has not changed much because a collective of old employees does not have the impression of truly being owners. Their shop is at the end of the still monopolised chain of state goods distribution and no individual employee is permitted to do what he/she likes with his or her individual share in the shop. ${ }^{19}$ The true feeling of ownership is only felt once one has such freedom. Thus, there has been little or no change in the quality and selection of goods and services in these shops. In contrast, the sale of retail trade or services outlets to new owners resulted in a completely different picture, featuring wider selection, polite service, more modern sales style, and the feeling that people like to work and work well.

Remnants of central planning. Retail trade outlets now being commercialised and privatised still lack working capital, distribution and transport infrastructure, logistics, raw materials and other goods supply, and storage facilities. These all belong to their former 'parents', the great regional monopolies of retailing-the so-called torgi.

In 1990 as many as $30 \%$ of these torgi signed agreements with the former Soviet Ministry of Trade (which has successors now) to lease their property, with additional rights to buy it when the leases expire. Only the court is able to dissolve those agreements, and only in case of serious infringments. If torgi do not violate their agreements, small shops will continue to lack adequate access to working capital, transport and storage facilities. This problem impedes the 


\section{J. Gács, I. A. Karimov \& C. M. Schneider}

separation of potential objects for SSP. Many facilities that have broken away from the torgi empires have preserved their monopoly status regionally and inter-regionally. Thus the problem is not simply solved by breaking up the great monopolies.

Loss-making trade and services in remote rural areas. Much of the trade and, especially, services in remote rural regions was historically substantially subsidised for an extended period of time. Now, under commercialisation, they have difficulty just to survive. Although economically it is inefficient, socially it is necessary to maintain them for a long time. Without infrastructure, rural areas will further deteriorate.

High degree of monopolisation of wholesale trade. For more than seven decades Russia has had a unified, centralised system of storage facilities upon which the retail shops were totally dependent. The lack of an adequate infrastructure on the supply side of the privatised retail trade and service outlets causes problems for the entire process. The viability of the single units is questionable and their operation risky. In a number of regions, successful privatisation of small retail outlets without accompanying privatisation of wholesale networks is leading to a paralysis of retail trade and consumer services. The newly privatised shops are required to find storage facilities, transport, suppliers and so on by themselves; something quite new for someone growing up under central distribution systems. Again, back in $1990100 \%$ of wholesale networks signed agreements with the former Soviet Ministry of Trade to lease their property, with additional rights to buy after leasing agreements expire-agreements which only the courts can dissolve.

Vague property rights and bureaucratic procedures. Russian SSP, and especially the potential participation of outsiders, is also still troubled by immature property rights legislation and the complete lack of a state programme supporting small entrepreneurship. For most business activities no licence is required, but the new entrepreneur must get approval for his or her business profile from his or her future competitors-the still state-owned monopolies. Also, the documents required for opening a small business are substantial in number and the process is quite onerous, though not necessarily complex.

Current decline in demand for outlets offered for auction. The most recent tendency, along with a rapidly growing number of units sold, is a sharp decline in selling prices and the contraction of demand in general. ${ }^{20}$ This fact is attributed to the tightening of monetary policy by the Central Bank of Russia in the second quarter of 1992 .

The recent decline in demand in the auctions for outlets is likely to be reversed with the introduction of personal privatisation accounts and vouchers that was expected towards the end of 1992. (These vouchers were to be introduced by 1 November 1992) The other problems can hardly be solved within the next few months or even years. There are some elegant solutions; for instance, transformation of torgi into joint stock companies which belong to their former subsidiaries-the retail trade outlets. ${ }^{21}$ But these solutions require a consensus of all parties involved and, not least, plenty of time. 


\section{Conclusions}

Small-scale privatisation in the past four years has contributed to and stimulated the emergence of the private sector in Central and Eastern Europe and Russia. The importance of this sector in the whole economy has expanded dramatically. The share of private sector sales revenue has increased substantially and most of the countries have gone from having virtually no private sector ten or less years ago to having a full-fledged private sector in retail trade, services and some manufacturing by June 1992.

In most countries of the region the privatisation of state property acted as a catalyst in the stimulation of new business, while in some countries, like Hungary and Poland, earlier deregulation and longer traditions rendered the privatisation of existing state-owned outlets less important and the establishment of new businesses more significant. SSP has also been responsible for altering the population's perspective and psychological disposition to the merits of private initiative.

In addition, the quality of goods and service, the general level of selection, including imported products, as well as the presentation and style of sale have all greatly improved. Partly thanks to effective macroeconomic policies and partly thanks to a more responsive retail trade sector, queues have disappeared and there is more to buy than people can afford. Everything from opening hours to advertising have seen significant changes. The number of shops has increased dramatically, convenience has improved in many ways, and competition has been ignited among domestic retailers and service people. There is hope that this may reverberate all the way through the up-stream supply channels. The populations are becoming educated about the functions (the advantages and disadvantages) of a market economy.

Some progress has been achieved in establishing and developing an entrepreneurial class, as well as in the creation of the infrastructure necessary to support SSP and the subsequent operation of these new enterprises. Business has become much freer relative to the past, though it is not always easy to become an entrepreneur and operate a retail or service outlet in the private sector. Nevertheless, the establishment of a background of institutional support is lagging well behind the growth of privatised business. This feature is partly responsible for the hardships newly privatised businesses must endure when they start operation and for the failure of some new businesses.

The progress of the financial sector, including the infrastructure of banks and credit institutions, is of crucial importance for further development of the small-scale sector. Without massive credit lines on favourable conditions, the majority of the new entrepreneurs may have to close their new venture before their ability to conduct business has been proven one way or the other. Another useful form of support, unfortunately not very often utilised, is a system of tax breaks and investment incentives for new entrepreneurs.

Some SSP programmes, or their implementation, have shown a clear preference for former employees and/or managers of the outlets targeted for privatisation (Poland, former East Germany and Russia), while others (like those of the CSFR and Hungary) secured equal opportunities for outsiders (that is, nonemployees). The clear and across the board preference for the previous employees appears to be disadvantageous. If the workers receive the outlet virtually free, there will be too little incentive to restructure the business and rationalise 
staffing under economic conditions characteristic of the transition to a market economy. However, if buying the outlet is a substantial investment for them, then the arrangement carries a high risk, since they put all their savings and earnings into one enterprise, if they have such savings. In other cases, the lack of capital impedes the acquisition of potential enterprises.

A characteristic and common feature of SSP in each country is the preference for domestic investors, or even the exclusion of foreign ones. In countries embarking on a prolonged process of privatising a dominant share of stateowned business, it is justifiable to secure prospective indigenous entrepreneurs (lacking the necessary capital to compete with foreign bidders) a fair opportunity for access to small-scale businesses. Each country has made provisions to limit foreign involvement. However, no such provisions can be complete. The Czechs, for example, are seriously concerned; despite the exclusion of foreigners from the first wave of auctions for retail trade outlets, a major part of this sector is now owned by Germans. In Hungary, the exclusion of foreigners from bidding for 3000 privatised outlets means nothing compared to the more than 100000 other outlets they can buy either one by one or in the form of networks.

As for the speed of SSP, we have seen very swift programmes (CSFR and Poland) and a slow one (Hungary). The German case, where it was also rapid, must be considered in the context of its peculiarity (the involvement of West German capital) and the speed of Russian SSP cannot yet be measured. Rapid privatisation has its obvious advantages: a quick transition from coordination by central planning to trade without any inefficient transitional method of coordination and the avoidance of the detrimental effects of spontaneous privatisation, or decapitalisation. One should be aware of the fact, however, that the faster the SSP process is, the more complaints can be expected about loss of privatisation revenue, unclear bidding procedures and corruption.

A SSP programme organised in a short period of time does not guarantee completion of the privatisation process. Guidelines and procedures for a second round of SSP may soon have to be formulated in order to encourage and regulate the outright sale of premises after the renting contracts expire and property rights of premises are clarified.

In order to ensure truly brisk SSP, some countries deliberately avoided the application of very detailed, intricate regulations. Policy makers in the CSFR, for instance, were much in favour of having only a skeleton of laws and well specified institutions to carry out the SSP. Polish regulation was also very loose and simple, and also reflected a full trust in the initiatives of local authorities.

The favourable effects of a quick privatisation process can easily be eliminated by tardy privatisation of monopolised wholesale trade and/or upstream suppliers. Czechoslovakia, Hungary and Poland each tried to compensate for the delay in this area by effectively deregulating entry to these markets and liberalising imports. It remains to be seen how the Russian private sector can survive without comparable support from trade deregulation and inflow of imports.

\section{Notes}

* The authors wish to thank all the participants of the workshop for their valuable contributions and those leading policy makers and scholars who took time from their extremely busy schedules to meet with us and inform us about the unique 
characteristics regarding SSP in their country. Other contributions notwithstanding, views or opinions expressed herein are solely those of the authors and do not necessarily represent those of the International Institute for Applied Systems Analysis or of its National Member Organisations. Any omissions or errors remain those of the authors.

1. The starting price refers to the price which the auctioneer first suggests.

2. Commercialisation refers to an enterprise achieving the status of being financially and managerially independent. This definition, used by the International Monetary Fund (IMF), also best corresponds to the meaning of the term in Russian.

3. One must register to become a legal entity in Russia, otherwise one is considered a physical entity. The procedure is fairly complicated and time consuming.

4. This city had been more commonly known as Gorky in the past. During the transition, it regained its historical name. According to the old Russian tradition, people often refer to it as Nizhny.

5. Industrial ministries and large state enterprises directly own almost $100 \%$ of retail trade and consumer services in certain areas, such as oil extracting and coal mining regions, metallurgy, and nuclear energy centres. These ministries and enterprises were required to sell off their free-access retail shops and service units by the end of 1992. The only exceptions are the shops located at oil wells, gold mines, and other very inaccessible locations.

6. The binding conditions include one or (rarely) more of the following three:

(1) preservation of the former type of business,

(2) perpetuation of the employment of the persons previously working at the outlet or enterprise, and.

(3) obligation to invest.

Such a contest is arranged primarily in rural areas and small cities, where the profile of the retail outlet is important for the population. The only participants allowed to bid are employees of the enterprise to be sold and residents (physical entities) living in the vicinity.

7. The only participants permitted to enter such a contest are those who are ready to provide necessary financial injections. The winner might not be the highest bidder, but the one who best satisfies the criteria of the competition.

8. The status of citizens from other Republics of the former Soviet Union remains unclear; in most cases, they are allowed to participate by default.

9. Again, the status of the residents of former Soviet Republics remains unclear. In small cities and in rural areas, these 'foreign' residents normally find it extremely difficult to bid owing to the obvious social and political constraints. However, organisations from former Republics of the USSR have widespread operations, for example, in the Moscow property market.

10. The network consisted of approximately 8000 retail shops: 4500 food, 3000 nonfood, and the rest large department stores and mixed shops.

11. See Müller (1991).

12. According to a new law, introduced on 29 August 1992, tenants of these 4700 outlets will have a 45-day period to apply for the purchase of the shop they currently rent. They will have the opportunity to buy it without auction at the book value of the premises or at the starting price of a fictitious auction.

13. Privatisation of wholesale companies has started; they will be privatised outside the framework of SSP.

14. The source of this information, as of many other aspects of SSP in Hungary summarised above, is Palócz (1992).

15. Quoted by Tamowicz et al. (1992). In compiling this summary of Polish SSP we have relied heavily on this remarkable study.

16. For example, in Novosibirsk oblast' revenue from SSP has reached an amazing 300 million rubles, while in Omsk oblast' not a single ruble has come in yet from privatisation. 


\section{J. Gács, I. A. Karimov \& C. M. Schneider}

17. There is even open opposition to reform from local authorities in places like Voronezh and Kursk.

18. Even in Nizhny, the pioneer in small scale privatisation, there is a conflict between local authorities and GAZ - the giant Volga car factory-with respect to this issue. The car producer, with all its auxiliary operations, possesses more economic clout than all the city's other enterprises together, including those under municipal authority.

19. Following the traditional and conventional communist/socialist principle, each employee received an equal share in an operation, regardless of fairness or effort. Not only has this provided plenty of incentive to 'stroll along' as a free rider, but the employees must now be unanimous in a bid to sell their outlet. No individual can sell his or her share. In only 52 cases so far did employees actually agree to sell to a single entrepreneur-a very small percentage of the total number of shops privatised by transfer to employees.

20. In Nizhny, for example, on 4 April 1992, 22 outlets were sold for between 3 million and 5 million rubles each, and 80 bidders participated. At another auction in late May, 10 outlets were auctioned to only 20 bidders, and prices were around 1 million rubles apiece.

21. There are already precedents of this kind in Novosibirsk, Omsk and Volgograd.

\section{References}

Marek Dabrowski, 'Privatisation in Poland,' Communist Economies and Economic Transformation, 3, 3, 1991.

Péter Félix, 'The Business Finds Its Way-Pre-Privatisation', Heti Világgazdaság, 6 June 1992 (in Hungarian).

Irena Grosfeld \& Paul Hare, 'Privatisation in Hungary, Poland and Czechoslovakia', The European Economy, 1991, No. 2, 1991.

Eva Klvacova, 'Czechoslovak Privatisation and Foreign Investors', Privatisation Newsletter of Czechoslovakia, 1, October 1991.

Margie Lindsay, Developing Capital Markets in Eastern Europe: a Business Reference (London, Pinter, 1992).

György Matolcsy, Years of Our Recovery-The Hungarian Privatisation: Trends, Facts, Examples (Budapest, Research Institute of Privatisation, 1991), (in Hungarian).

Jürgen Müller, Mergers in East Germany (Toronto, Centre for International Studies, University of Toronto, 1991).

Ostdeutschland 1992 und 1993: Zerbrechliche Aufwärtsbewegung (Berlin/Halle, Institut für Wirtschaftsforschung Halle, 1992).

Erzsébet Páczi, 'Complications-A Different Way. Prague: Privatisation of Retail Trade', Figyelö, 28 May 1992 (in Hungarian).

Éva Palócz, The Emergence and Implementation of the Small Scale Privatisation Programme in Eastern European Countries: The Case of Hungary (Mimeo, Budapest, 1992).

Privatisation in Poland-Programme and Achievements (Ministry of Privatisation, Warsaw, 1991).

Ben Slay, An Overview of the Private Sector and Privatisation in Poland (Munich, Research Institute of Radio Free Europe/Radio Liberty, 1991).

P. Tamowicz, T. Aziewicz \& M. Stompór, 'Small Privatisation-Polish Experiences 1990-1991', Paper prepared for the World Bank at the Gdansk Institute for Market Economics, Gdansk, 1992. 
